\title{
Analysis of dynamic stiffness of arch bridges by means of the first natural frequency
}

\author{
Slawomir Karas ${ }^{1, *}$, Radoslaw Wrobel $^{2}$ \\ ${ }^{1}$ Road and Bridge Department, Lublin University of Technology, Nadbystrzycka 40, 20-814 Lublin, Poland \\ ${ }^{2}$ Budimex S.A., Stawki 40, 01-040 Warszawa, Poland
}

\begin{abstract}
Arch bridges have always boasted a strong aesthetic value. However, their design is challenging due to dynamic excitations. It regards, above all, an area up to $1 / 4$ of a bridge length. In bridge dynamics numerical analyses, the basic importance is attached to the natural vibration frequency corresponding to the first bending mode. The multiple first mode is connected to the horizontal shift of a platform or arches, additionally coupled with the deformation corresponding to torsion. In the bridge standards, the first bending mode was adopted as default followed subsequently by higher rank modes of torsional or transversal shapes which do not always occur. This paper describes fourteen numerical models of various arches used in bridge design. The arch bridge, of vertical arches, constitutes a reference. Other models are their varieties through a change of the arch height, a method of connecting platforms and arches at a head and their resulting interaction. Furthermore, variability of arch tilts from a vertical plane was discussed. Conclusions are not unanimously final from the technical point of view; nevertheless, certain beneficial solutions, corresponding to the models of structures of higher natural frequencies, can be indicated.
\end{abstract}

\section{Introduction}

Arch bridges come in the variety of forms [1]. Their types can be classified according to:

- a form of an arch and their number,

- a static scheme of an arch, including several joints and how they are attached to a platform,

- a proportion of stiffness between an arch and a platform, e.g. flexible arch - stiff platform,

- tied arch and arch,

- a type of hangers used,

- a location of an arch in relation to a platform,

- other criteria.

Even in terms of statics, arch bridge design, regardless whether for the purposes of railways or roads, may face numerous problems in stresses distribution. In practice, a numerical analysis is indispensable.

Dynamics is much more complex. Here, the modal analysis as implementation of FEM is applied. At present, the Fourier's harmonic analysis is rarely in use. In case of dynamics, apart from examining limit states, i.e. ULS and SLS in relation to strain/stress amplitudes, deformations and accelerations, also damping vibrations and possible excitations are important. In the face of such complexity, it is necessary to look for a relatively simple measure for purposes of preliminary assessment of a model of bridge to be designed. Most often, the measure is the shape and value of the first natural vibration frequency [2-4]. Such an approach is to be found among the European standards, where it is a simplified criterion for simple (non-complex) structures, simple beams [5]. Even the best design cannot replace a proofing test load performed on a constructed bridge, both in static and dynamic terms. Nevertheless, it is assumed that results of the numerical model analysis should be consistent with in situ measurements.

The paper discusses fourteen numerical models of bridges where all of them are modifications of the basic reference model, namely, a real railway bridge structure (Fig. 1). An assumed scope of the research of arch bridges is not exhaustive, nevertheless, it sheds light on the question of dynamic stiffness.

\section{Assumptions and the range of the research}

The paper discusses fourteen numerical models of bridges where all of them were modifications of the basic reference model, namely, a real railway bridge structure (Fig. 1).

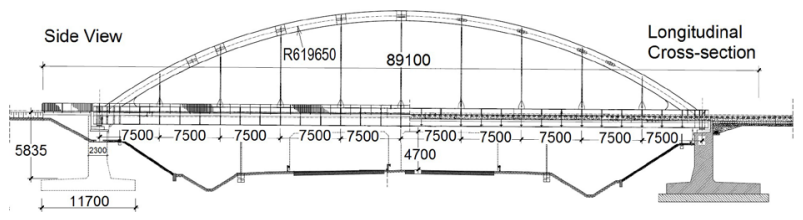

Fig. 1. Reference bridge, load class LM71, $\alpha=1.21$; [3].

The assumed scope of the research of arch bridges was not exhaustive, nevertheless, it shed light on the

\footnotetext{
* Corresponding author: s.karas@pollub.pl
} 
question of dynamic stiffness. The reference bridge characteristics were: steel S355; cross-section of welded arch box $\mathrm{h}=1,200 \mathrm{~mm}$, width $\mathrm{b}=600 \mathrm{~mm}$, and thickness $\mathrm{t}=30 / 22 \mathrm{~mm}$; hanger rods $--\mathrm{d}=100 \mathrm{~mm}$. Bearing in mind further adaptations, an original steel orthotropic platform was replaced by RC plate of the height $\mathrm{h}=45 \mathrm{~cm}$, made with concrete of $\mathrm{C} 30 / 37$ strength class.

Massive abutments, enough to carry the thrust, were also assumed. Therefore, it was not a tied arch scheme. Characteristics of bridge geometry were: $\operatorname{span} \mathrm{L}=75 \mathrm{~m}$; segment of circular arc with radius $\mathrm{R}=61.95 \mathrm{~m}$ (angle $\alpha=71^{\circ}$ ); arch elevation $\mathrm{f}=11 \mathrm{~m}$; arch axle spacing $5.5 \mathrm{~m}$; Langer system of hangers fixed at their ends. Steel transverse stiffeners between arches had a box form of $\mathrm{h}=300 \mathrm{~mm}$ and $\mathrm{b}=600 \mathrm{~mm}$.

The analyses were carried out regarding the following groups of models.

\subsection{Group 1. Testing an influence of hinge joints}

Model 1. It differed from the original arch by: a parabolic arch shape, elevation amounted to $\mathrm{f}_{\mathrm{M} .1}=12 \mathrm{~m}$ and hinged connection between arches, plate and abutment. The hangers were clamped at the ends.

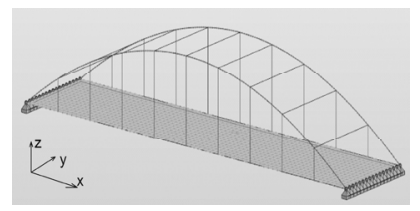

Fig. 2. Model 1.

Model 2. Hangers had hinges at their ends.

Model 3. Hangers were clamped. The arch was circular and its elevation was fixed $\mathrm{f}_{\mathrm{M} .3}=\mathrm{f}_{\mathrm{M} .2}=12 \mathrm{~m}$.

Model 4. As in the Model 1; however, hangers had an articulation at the ends, $\mathrm{f}_{\mathrm{M} .4}=12 \mathrm{~m}$.

\subsection{Group 2. The influence of arch elevation}

Additional horizontal stiffeners, HEB 200, were used. In this case, the stiffening system had a form of a truss. The arch had a parabolic scheme and hangers had an articulation at the ends.

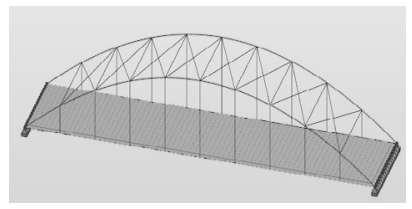

Fig. 3. Model 5.

Model 5. $\mathrm{f}_{\mathrm{M} .5}=10 \mathrm{~m}$.

Model 6. $\mathrm{f}_{\mathrm{M} .6}=12 \mathrm{~m}$.

Model 7. $\mathrm{f}_{\text {M. }}=15 \mathrm{~m}$.

Model 8. $\mathrm{f}_{\mathrm{M} .8}=18.75 \mathrm{~m}$.

\subsection{Group 3. Arches tilted from the vertical}

Model 9. The $1 \mathrm{~m}$ tilt at the keys of arches (4.5 deg)

Model 10. The tilt by 9 deg.

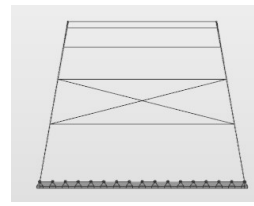

Fig. 4. Model 10.

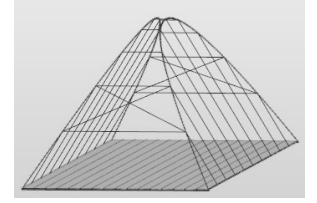

Fig. 5. Model 11.
Model 11. The horizontal distance between the keys equalled $1 \mathrm{~m}$ i.e. the tilt was of $10.2 \mathrm{deg}$.

\subsection{Group 4. Analysis of Nielsen hanger systems}

Arches were tilted inwardly by 9 deg. A stiffening frame was reduced to a bar system where each bar was perpendicular to the arches. The arch was parabolic with the elevation $\mathrm{f}=12.5 \mathrm{~m}$.

Model 12. Spacing at the concrete plate level equalled $15 \mathrm{~m}$.

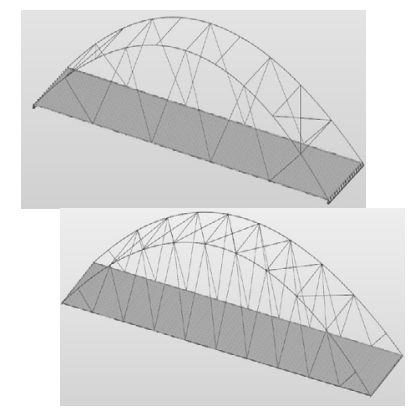

Fig. 6. Model 12.

Fig. 7. Model 13.

Model 13. Hangers' spacing was broadened to $7.5 \mathrm{~m}$. Again, the stiffening system had the truss form.

\subsection{Group 5. Model 14.}

A model of the cathedral type of an arch bridge, with an upper platform for traffic, was constructed. Concrete was used. The arch cross-section amounted to $60 \times 120 \mathrm{~cm}$. Elevation $-12.5 \mathrm{~m}$. Arches tilted by $10 \mathrm{deg}$.

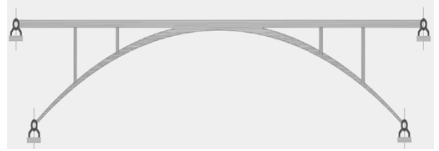

Fig. 8. Model 14.

\section{Method of the analysis}

The purpose of the paper was a relative comparison of the models.

Calculations were carried out in Robot Structural Analysis Professional 2017 using the spatial bar element 
$(\mathrm{e} 1, \mathrm{p} 3)$ and the shell element $(\mathrm{e} 3, \mathrm{p} 3)$ for the plate. In all models, regarding both cases where FEM elements were used, the plate and the beam, the max. distance between mesh vertices was max. $50 \mathrm{~cm}$, in relation to the real structure dimensions.

Other models were also analysed, especially the ones allowing for a horizontal movement over one of the supports. However, in such cases the influence of freeing movement in the longitudinal direction on the arch was insignificant.

The results were presented in the tables, although the mode visualisations did not include all the models some of them were only described.

The low values of the natural vibration frequencies resulted from adopted assumptions. In particular, that was due to the omission of: the weight of removable loads, the weight and stiffness of node plates, additional ties in bottom chords etc.

In the paper the following abbreviations were used:

- B-y - bending in y plane,

- B-x - bending in $\mathrm{z}$ plane or the translation of an arch in its keys in y direction,

- T- $\mathrm{x}$ - torsion about $\mathrm{x}$ axis,

- M.1 - Model 1, for instance.

\section{Numerical results}

\subsection{Results obtained for Group 1}

Table 1. Model 1.

\begin{tabular}{|c|c|c|c|}
\hline No. & Mode & $\begin{array}{c}\text { Value } \\
{[\mathrm{Hz}]}\end{array}$ & Depiction \\
\hline $\mathrm{n}_{1}$ & & 0.74 & $\mathrm{~B}-\mathrm{y}$ \\
\hline $\mathrm{n}_{2}$ & & 0.79 & $\mathrm{~B}-\mathrm{x}$ \\
\hline $\mathrm{n}_{3}$ & & 1.49 & $\mathrm{~T}-\mathrm{x}$ \\
\hline $\mathrm{n}_{4}$ & & 1.56 & $\mathrm{~B}-\mathrm{y}$ \\
\hline $\mathrm{n}_{5}$ & & 1.88 & $\mathrm{~T}-\mathrm{x}$ \\
\hline
\end{tabular}

The nodes $\mathrm{n}_{1}$ and $\mathrm{n}_{4}$ were of bending type. They corresponded to the first and second modes of a simple beam. Both, arches and the deck have 1 full sinusoid (function domain: $\langle 0 ; 2 \pi>$ ) and 2 sinusoidal shapes, respectively. However, the analysed structure was significantly more complex than the simple beam. In the case of the beam, the first mode had a shape of $1 / 2$ of sinusoid, which indicates the occurrence of greater stiffness in case of arch bridge. The uniform translation of the upper arch parts was a warning signalising the lack of transverse stiffness in this part of the structure. Also, it should have been noticed that the ratio of bending frequencies amounted to

$$
n_{4} / n_{1}=2.11 \rightarrow \sim 211 \%
$$

In the qualitative sense, the obtained results overlapped with those in the Table 1 . The presence of two bending modes directly successive, $\mathrm{n}_{2}$ and $\mathrm{n}_{3}$, indicated better dynamics of the structure (cf. tables 1.24).

Table 2. Model 2.

\begin{tabular}{|c|c|c|c|}
\hline No. & Mode & $\begin{array}{c}\text { Value } \\
{[\mathrm{Hz}]}\end{array}$ & Depiction \\
\hline $\mathrm{n}_{1}$ & 0.76 & $\mathrm{~B}-\mathrm{x}$ \\
\hline $\mathrm{n}_{2}$ & & 0.8 & $\mathrm{~B}-\mathrm{y}$ \\
\hline $\mathrm{n}_{3}$ & & 1.6 & $\mathrm{~B}-\mathrm{y}$ \\
\hline $\mathrm{n}_{4}$ & & 1.66 & $\mathrm{~T}-\mathrm{x}$ \\
\hline $\mathrm{n}_{5}$ & & 1.94 & $\mathrm{~T}-\mathrm{x}$ \\
\hline
\end{tabular}

Table 3. Model 3

\begin{tabular}{|c|c|c|c|}
\hline No. & Mode & $\begin{array}{c}\text { Value } \\
{[\mathrm{Hz}]}\end{array}$ & Depiction \\
\hline $\mathrm{n}_{1}$ & & 0.74 & $\mathrm{~B}-\mathrm{y}$ \\
\hline $\mathrm{n}_{2}$ & & 0.78 & $\mathrm{~B}-\mathrm{x}$ \\
\hline $\mathrm{n}_{3}$ & & 1.46 & $\mathrm{~B}-\mathrm{y}$ \\
\hline $\mathrm{n}_{4}$ & & 1.47 & $\mathrm{~T}-\mathrm{x}$ \\
\hline $\mathrm{n}_{5}$ & & 1.89 & $\mathrm{~T}-\mathrm{x}$ \\
\hline
\end{tabular}

Table 4. Model 4

\begin{tabular}{|l|c|c|c|}
\hline No. & Mode & $\begin{array}{c}\text { Value } \\
{[\mathrm{Hz}]}\end{array}$ & Depiction \\
\hline $\mathrm{n}_{1}$ & 0.73 & $\begin{array}{c}\mathrm{B}-\mathrm{x} \\
\mathrm{B}-\mathrm{y}\end{array}$ \\
\hline $\mathrm{n}_{2}$ & 0.73 & $\mathrm{~B}-\mathrm{x}$ \\
\hline $\mathrm{n}_{3}$ & & 1.43 & $\mathrm{~T}-\mathrm{x}$ \\
\hline $\mathrm{n}_{4}$ & & 1.46 & $\begin{array}{c}\mathrm{B}-\mathrm{x} \\
\mathrm{B}-\mathrm{y}\end{array}$ \\
\hline $\mathrm{n}_{5}$ & & 1.86 & $\mathrm{~T}-\mathrm{x}$ \\
\hline
\end{tabular}


Commenting on the results obtained from the analysis of the models in the Group 1, a conclusion that at the assumed span of $75 \mathrm{~m}$ the shape of the parabolic arch, and the arch in the form of a circle arc are similar can be drawn. Also, the differences between the stiff and articulated fastening of the hangers were insignificant. According to the Table 4, the modes corresponding to $n_{1}$ and $n_{3}$ corresponded to the bending effect on two planes, $\mathrm{x}$ and $\mathrm{y}$.

More specifically, the highest values of bending vibrations were noted for the Model 2 - the parabolic arch with the articulated fastening of hangers.

\subsection{Group 2}

Here, the inflow of the arch elevation was investigated.

Table 5. Model 5; $\mathrm{H}=10 \mathrm{~m} ; \mathrm{H} / \mathrm{L}=0.13 \mathrm{~m}$.

\begin{tabular}{|c|c|c|c|}
\hline No. & Mode & $\begin{array}{c}\text { Value } \\
{[\mathrm{Hz}]}\end{array}$ & Depiction \\
\hline $\mathrm{n}_{1}$ & & 0.8 & $\mathrm{~B}-\mathrm{y}$ \\
\hline $\mathrm{n} 2$ & & 1.58 & $\mathrm{~B}-\mathrm{y}$ \\
\hline $\mathrm{n}_{3}$ & 1.64 & $\mathrm{~B}-\mathrm{x}$ \\
\hline $\mathrm{n}_{4}$ & & 1.87 & $\mathrm{~T}-\mathrm{x}$ \\
\hline $\mathrm{n}_{5}$ & & 2.14 & $\mathrm{~B}-\mathrm{y}$ \\
\hline
\end{tabular}

Table 6. Model 6; $\mathrm{H}=12 \mathrm{~m} ; \mathrm{H} / \mathrm{L}=0.16 \mathrm{~m}$.

\begin{tabular}{|c|c|c|c|}
\hline No. & Mode & $\begin{array}{c}\text { Value } \\
{[\mathrm{Hz}]}\end{array}$ & Depiction \\
\hline $\mathrm{n}_{1}$ & 0.79 & $\begin{array}{c}\mathrm{B}-\mathrm{x} \\
\mathrm{B}-\mathrm{y}\end{array}$ \\
\hline $\mathrm{n}_{2}$ & 1.57 & $\mathrm{~B}-\mathrm{x}$ \\
\hline $\mathrm{n}_{3}$ & & 1.6 & $\mathrm{~B}-\mathrm{y}$ \\
\hline $\mathrm{n}_{4}$ & & 1.85 & $\mathrm{~T}-\mathrm{x}$ \\
\hline $\mathrm{n}_{5}$ & & & \\
\hline
\end{tabular}

Table 7. Model 7; $\mathrm{H}=15 \mathrm{~m} ; \mathrm{H} / \mathrm{L}=0.2 \mathrm{~m}$.

\begin{tabular}{|c|c|c|c|}
\hline No. & Mode & $\begin{array}{c}\text { Value } \\
{[\mathrm{Hz}]}\end{array}$ & Depiction \\
\hline $\mathrm{n}_{1}$ &
\end{tabular}

\begin{tabular}{|l|l|l|l|}
\hline $\mathrm{n}_{2}$ & 1.46 & B-y \\
\hline $\mathrm{n}_{3}$ & & 1.6 & $\mathrm{~B}-\mathrm{y}$ \\
\hline $\mathrm{n}_{4}$ & 1.79 & $\mathrm{~T}-\mathrm{x}$ \\
\hline $\mathrm{n}_{5}$ & & 2.34 & $\mathrm{~B}-\mathrm{y}$ \\
\hline
\end{tabular}

Table 8. Model 8; $\mathrm{H}=18.75 \mathrm{~m} ; \mathrm{H} / \mathrm{L}=0.25 \mathrm{~m}$.

\begin{tabular}{|c|c|c|c|}
\hline No. & Mode & $\begin{array}{c}\text { Value } \\
{[\mathrm{Hz}]}\end{array}$ & Depiction \\
\hline $\mathrm{n}_{1}$ & 0.75 & $\mathrm{~B}-\mathrm{y}$ \\
\hline $\mathrm{n}_{2}$ & & 1.32 & $\mathrm{~B}-\mathrm{y}$ \\
\hline $\mathrm{n}_{3}$ & & 1.58 & $\mathrm{~B}-\mathrm{y}$ \\
\hline $\mathrm{n}_{4}$ & & 1.69 & $\mathrm{~T}-\mathrm{x}$ \\
\hline $\mathrm{n}_{5}$ & & 2.39 & $\mathrm{~B}-\mathrm{y}$ \\
\hline
\end{tabular}

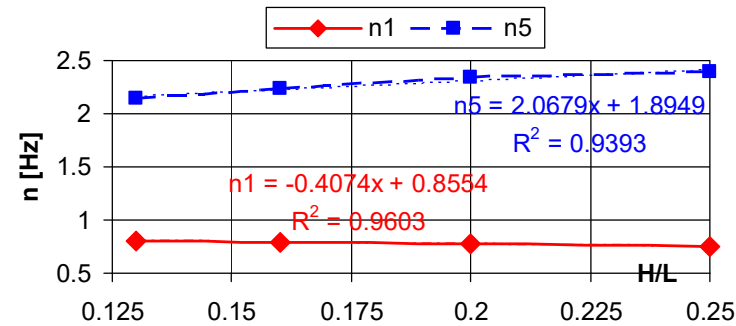

Fig. 9. Distribution of $\mathrm{n}_{1}$ and $\mathrm{n}_{5}$ values for models of the Group 4 .

Drawing conclusions at this stage regarded, above all, the variability of values $n_{1}$ and $n_{5}$ to which bending modes corresponded. $\mathrm{n}_{1}$ decreased with the increase of the elevation of the arch, while $\mathrm{n}_{5}$ increased, which was depicted in the Fig. 9. Even though lines in both cases were curved, their variability was insignificant, (2-3), therefore linear regression was applied.

The highest value of $n_{1}$ occurs for the Model 5, where

$$
n_{1}(M .8) / n_{1}(M .5)=0.9375 \rightarrow \sim 94 \%
$$

and appropriately $\mathrm{n}_{5}$ rose somewhat

$$
n_{5}(M .8) / n_{5}(M .5)=1.1168 \rightarrow \sim 112 \%
$$




\subsection{Group 3}

The influence of the tilt of the arch planes towards the inside of the bridge was analysed. The examined parabolic arch was elevated to $12.5 \mathrm{~m}$.

Table 9. Model 9; $\alpha=4.5^{\circ}$.

\begin{tabular}{|c|c|c|c|}
\hline No. & Mode & $\begin{array}{c}\text { Value } \\
{[\mathrm{Hz}]}\end{array}$ & Depiction \\
\hline $\mathrm{n}_{1}$ & 0.80 & $\mathrm{~B}-\mathrm{y}$ \\
\hline $\mathrm{n}_{2}$ & & 1.50 & $\begin{array}{c}\mathrm{B}-\mathrm{x} \\
\mathrm{T}-\mathrm{x}\end{array}$ \\
\hline $\mathrm{n}_{3}$ & & 1.61 & $\mathrm{~B}-\mathrm{y}$ \\
\hline $\mathrm{n}_{4}$ & & 1.90 & $\mathrm{~T}-\mathrm{x}$ \\
\hline $\mathrm{n}_{5}$ & & 2.20 & $\begin{array}{c}\mathrm{B}-\mathrm{x} \\
\mathrm{T}-\mathrm{x}\end{array}$ \\
\hline
\end{tabular}

Table 10. Model 10; $\alpha=9^{\circ}$.

\begin{tabular}{|c|c|c|c|}
\hline No. & Mode & $\begin{array}{c}\text { Value } \\
{[\mathrm{Hz}]}\end{array}$ & Depiction \\
\hline $\mathrm{n}_{1}$ & 0.80 & $\mathrm{~B}-\mathrm{y}$ \\
\hline $\mathrm{n}_{2}$ & 1.61 & $\begin{array}{c}\mathrm{B}-\mathrm{x} \\
\mathrm{T}-\mathrm{x}\end{array}$ \\
\hline $\mathrm{n}_{3}$ & & 1.67 & $\begin{array}{c}\mathrm{B}-\mathrm{x} \\
\mathrm{T}-\mathrm{x}\end{array}$ \\
\hline $\mathrm{n}_{4}$ & & 1.99 & $\mathrm{~T}-\mathrm{x}$ \\
\hline $\mathrm{n}_{5}$ & & 2.26 & $\begin{array}{c}\mathrm{B}-\mathrm{x} \\
\mathrm{B}-\mathrm{y}\end{array}$ \\
\hline
\end{tabular}

Table 11. Model 11; $\alpha=10.2^{\circ}$.

\begin{tabular}{|c|c|c|c|}
\hline No. & Mode & $\begin{array}{c}\text { Value } \\
{[\mathrm{Hz}]}\end{array}$ & Depiction \\
\hline $\mathrm{n}_{1}$ & 0.78 & B-y \\
\hline $\mathrm{n}_{2}$ & & 1.57 & B-y \\
\hline $\mathrm{n}_{3}$ & & 2.20 & B-y \\
\hline $\mathrm{n}_{4}$ & & 2.70 & $\mathrm{~T}-\mathrm{x}$ \\
\hline $\mathrm{n}_{5}$ & & 2.93 & B-y \\
\hline
\end{tabular}

First modes were of the bending form and were characterised by an almost constant value of natural frequencies. In the cases of Models 9 and 10, apart from bending forms, there were modes of torsion shapes. However, in the last case of the Model 11, there was only one torsion mode, the forth one. The other ones were bending modes. This indicated that the bridge would work mainly on bending, which was a very beneficial result.

\subsection{Group 4}

Till this moment the bridges with vertical suspension systems were considered, the Langer system. Now, results obtained from the models with Nielsen hangers should be examined. The bridge arches were parabolic (non-circular) and elevated to $12.5 \mathrm{~m}$. Each of the arches was tilted inwardly by $9 \mathrm{deg}$. This arrangement has been further analysed.

Table 12. Model 12; spacing of $15 \mathrm{~m}$.

\begin{tabular}{|c|c|c|c|}
\hline No. & Mode & $\begin{array}{c}\text { Value } \\
{[\mathrm{Hz}]}\end{array}$ & Depiction \\
\hline $\mathrm{n}_{1}$ & 1.68 & $\mathrm{~B}-\mathrm{x}$ \\
\hline $\mathrm{n}_{2}$ & & 1.87 & $\mathrm{~B}-\mathrm{y}$ \\
\hline $\mathrm{n}_{3}$ & & 2.16 & $\begin{array}{c}\mathrm{B}-\mathrm{x} \\
\mathrm{T}-\mathrm{x}\end{array}$ \\
\hline $\mathrm{n}_{4}$ & & 2.4 & $\mathrm{~T}-\mathrm{x}$ \\
\hline $\mathrm{n}_{5}$ & & 2.63 & $\mathrm{~B}-\mathrm{y}$ \\
\hline
\end{tabular}

Table 13. Model 13; spacing of $7.5 \mathrm{~m}$.

\begin{tabular}{|l|c|c|c|}
\hline No. & Mode & $\begin{array}{c}\text { Value } \\
{[\mathrm{Hz}]}\end{array}$ & Depiction \\
\hline $\mathrm{n}_{1}$ & 1.34 & $\mathrm{~B}-\mathrm{x}$ \\
\hline $\mathrm{n}$ & & 2.14 & $\mathrm{~B}-\mathrm{y}$ \\
\hline $\mathrm{n}_{2}$ & & 2.35 & $\mathrm{~B}-\mathrm{y}$ \\
\hline $\mathrm{n}_{3}$ & \\
\hline
\end{tabular}

What was worrying in this case, was that the first mode corresponded to arches bending in plane $\mathrm{x}$, although, its value was almost twice higher than in the previous cases, admittedly. The most favourable result of the analysis of the modes and the corresponding values 
of natural vibration frequencies was obtained from the Model 13. Apart from the first mode, the remaining ones were bending in plane $\mathrm{y}$, while $\mathrm{n}_{5}$ had value of $4.05 \mathrm{~Hz}$. Therefore, it could be inferred that it was the most appropriate scheme of the arch bridge. The obtained result can also be extrapolated to the network arch suspension scheme which has not been analysed due to its relatively greater complexity.

\subsection{Group 5}

Here, the RC cathedral arch with open-spandrels was the subject of the analysis.

Table 14. Model 14.

\begin{tabular}{|l|l|l|l|l|}
\hline No. & Mode-y & Mode-x & $\begin{array}{l}\text { Value } \\
{[\mathrm{Hz}]}\end{array}$ & Depiction \\
\hline $\mathrm{n}_{1}$ & 1 & 1.79 & $\mathrm{~B}-\mathrm{y}$ \\
\hline $\mathrm{n}_{2}$ & & 2.65 & $\begin{array}{l}\mathrm{B}-\mathrm{y} \\
\mathrm{B}-\mathrm{x}\end{array}$ \\
\hline $\mathrm{n}_{3}$ &
\end{tabular}

This bridge varies from the afore-analysed structures, although it has been popularly used. At the design stage, the most important task was to transfer horizontal forces - thrust. Model 14 used arches tilted from the vertical plane by $10 \mathrm{deg}$. Apart from the column supports of the platform, there was an additional support located in the bridge key. The better the bridge support is, the better its dynamic features are - this assumption has been illustrated by the subsequent modes. In the variant of wall supports of the width equal to the width of the platform, which was not represented in this analysis, the values of the natural vibration frequency increase additionally. Similarly, when the width of the arch equals the width of the platform, i.e. replacing a beam arch with a cylindrical shell strip [6].

As far as dynamics is concerned, the arch bridge consistent with the Model 14 is similar to the bridge with diagonal hangers, Model 13.

\section{Conclusions}

The carried out comparative analysis has both qualitative as well as quantitative assessments.

14 models of 75 metre span arch bridges were constructed where a typical railway arch bridge served as a reference. The models were modified to include: parabolic and circular arch shapes, method of fixing hangers to the arch and the platform, variable elevation of the arch, increased stiffening of the arches in the span element. Furthermore, Langer and Nielsen hanger systems were discussed taking into consideration arch tilts from the horizontal plane, and finally, the model of the arch bridge with the upper traffic platform.

For the purposes of the conducted comparative analysis, the first modes and corresponding natural vibration frequencies were used.

No influence of the method of fixing hangers was established.

Moreover, the influence of the type of the arch curve was negligibly small.

An increase in the values of the natural vibration frequency in the cases where arches were tilted from their initial horizontal planes was noted, as well as the noticeable influence where the concentration of the Nielsen system hangers was greater.

The stiffest models in terms of dynamics were the Model 13 and the Model 14, where the conclusions from the first model examinations were applied.

\section{References}

1. M. Dębiński, M. Jukowski, S. Karaś, M. Kowal, A. Leniak-Tomczyk (Ed.: Karaś S.): Aesthetics of road structures, (Lublin University of Technology, 2016).

2. S. Karaś, A. Krasnowski, Roads and Bridges - Drogi i Mosty, 4 (2013).

3. F. Magalhães, Á. Cunha, E. Caetano, Eng. Struct. 30 (2008).

4. Wei-Xin Ren, Tong Zhao, I.E. Harik, J. Struct. Eng. 4 (2004).

5. EN 1991-2 Eurocode 1 : Actions on structures - Part 2: Traffic Loads on Bridges.

6. S. Karaś, P. Jamińska, Historyczne lubelskie mosty żelbetowe, W: Aktualne zagadnienia budownictwa komunikacyjnego : wydanie jubileuszowe z okazji 75-lecia Profesora Wacława Szcześniaka, (Oficyna Wydawnicza Politechniki Warszawskiej, 2015). 